Research Article

\title{
Elastin Expression in Sacrouterina Ligament is Weaker in the Women with Pelvic Organ Prolapse
}

\section{Ekspresi Elastin di Ligamentum Sakrouterina lebih lemah pada Perempuan dengan Prolaps Organ}

\author{
Andi Hasnawati, Trika Irianta, Eddy R. Moeljono \\ Department of Obstetrics and Gynecology \\ Faculty of Medicine University of Hasanuddin/ \\ Dr. Wahidin Sudirohusodo Hospital \\ Makassar
}

\begin{abstract}
Objective: The research aims at comparing the elastin immunolabeling in the uterosacral ligaments in women with pelvic organ prolapse and without pelvic organ prolapse (POP).

Methods: The research is done at Dr. Wahidin Sudirohusodo Hospital and education networking some hospitals the Obstetrics and Gynecological School of Medicine Hasanuddin University that began in January 2011 until April 2012. This research assessing expression of elastin on 35 women with a pop level III and IV and as control is 35 women without POP. Immunolabeling of elastin valued in staining checkings immunohistokimia uses antibodies elastin ( clone no. Ba-4 1:1600; Novacastra Laboratories Ltd, UK). The research was carried out by the cross sectional study. Mixed with chi-square. Level significance used is 0.05 .
\end{abstract}

Results: The results showed that the elastin immunolabeling in women with POP is decline on most sample expression with the intensity of elastin is weak (74.3\%). The most control with the intensity of elastin immunolabeling is moderate (48.6\%). Elastin immunolabeling seem significant in women with menopause and with BMI that overweight (all with $\mathrm{p}<0.05$ ). Other factors that contributed to the occurrence of pelvic organ prolapse are age, parity, history of childbirth, and the history of newborn's weight.

Conclusion: Elastin expression is weaker in the sacrouterina ligament of women with pelvic organ prolapse, thus it could contribute to the occurence of pelvic organ prolapse.

[Indones J OIbstet Gynecol 2012; 36-4: 188-93]

Keywords: elastin, pelvic organ prolapse, risk factor

\section{Abstrak}

Tujuan: Penelitian ini bertujuan membandingkan ekspresi elastin ligamentum sakrouterina pada perempuan dengan prolaps organ panggul dan tanpa prolaps organ panggul (POP).

Metode: Penelitian ini dilakukan di BLU RS Dr. Wahidin Sudirohusodo dan jejaring beberapa rumah sakit pendidikan bagian Obstetri dan Ginekologi Fakultas Kedokteran Universitas Hasanuddin yang dimulai pada Januari 2011 sampai April 2012. Penelitian ini menilai ekspresi elastin pada 35 perempuan dengan POP tingkat III dan IV, dan sebagai kontrol adalah 35 perempuan tanpa POP. Ekspresi elastin dinilai dengan pemeriksaan immunohistokimia menggunakan pewarnaan antibodi elastin (clone no. BA-4 1:1600; Novacastra Laboratories LTD, UK). Penelitian ini dilakukan secara cross sectional. Data diolah dengan chi-square. Tingkat signifikansi yang digunakan adalah 0,05.

Hasil: Hasil penelitian menunjukkan bahwa ekspresi elastin menurun pada perempuan dengan POP di mana ekspresi elastin pada sampel terbanyak dengan intensitas elastin lemah (74,3\%). Ekspresi elastin pada kontrol terbanyak dengan intensitas elastin moderat $(48,6 \%)$. Ekspresi elastin tampak signifikan pada perempuan dengan POP status post menopause dan dengan IMT yang overweight (semua dengan $p<0,05)$. Faktor lain yang ikut berperan pada kejadian prolaps organ panggul adalah usia, paritas, riwayat jenis persalinan, dan riwayat berat bayi yang dilahirkan

Kesimpulan: Ekspresi elastin lebih lemah di ligamentum sakrouterina dan ikut berkontribusi pada perempuan dengan prolaps organ panggul.

[Maj Obstet Ginekol Indones 2012; 36-4: 188-93]

Kata kunci: elastin, faktor risiko, prolaps organ panggul

Correspondence: Andi Hasnawati.: Jln. Mappala Blok E 25A No.13, Makassar. Telephone/mobile: 0811467402.

email: oyieobgyn@gmail.com

\section{INTRODUCTION}

Pelvic organ prolapse (POP) is a common and very disturbing health problem for women of all ages, and their treatment often requires a very high cost. Although POP is generally not fatal, but it can worsen the quality of life of patients, including abnormalities of the bladder, gastrointestinal system as well as sexual dysfunction. Along with the increase in life expectancy and the increasing elderly popu- lation the prevalence of pelvic organ prolapse is increasing. ${ }^{1}$

In 2005, Delancey said that the pelvic floor dysfunction is found in 300,000 to 400,000 women in the United States each year. It can be so severe that it requires surgery. The high prevalence of this disorder shows how important it is to change the paradigm of treatment for pelvic organ prolapse, from passive into active preventive paradigm. Pri- 
mary prevention is very important because $30 \%$ of operations per year are performed to correct pelvic floor dysfunction is a repeat surgery. ${ }^{2}$

Problems in the developed countries like the U.S. will sooner or later be experienced by Indonesia. Percentage of productive age population in Indonesia is quite high, and along time, they will be a part of the national health care group for elderly, in which POP is part of. Therefore, searching for the cause of POP is a challenge.

Although the incidence of POP is high, little is known about their underlying pathophysiology. Age, occupation, weight (BMI), parity, type of delivery, vaginal delivery using forceps or a vacuum device, the largest weight of child born, history of previous operation, history of medical ailments, menopausal status and use of hormone replacement therapy is a risk factor that is often associated with the incidence of POP. ${ }^{1,3-5}$

However, even nulliparous women without risk factors may suffer from POP. Therefore, genetic predisposition plays a role in both the incidence of this disease. When a woman with a mother or sister suffering from POP, the relative risk for suffering POP is 3.2. And if the mother or sister does not have a medical history of POP, the relative risk was $2.4^{3}$

By knowing the causes of pelvic floor disorders, we could find a therapy that will help to repair this condition, and, more importantly, a prevention strategy, a way to make a very related clinical priority. The mechanism of disease at the molecular level is not fully known, so it has not been widely implemented as prevention, and surgery remains the standard treatment option to date for approximately 100 years. ${ }^{6}$

One important part of the system is a proponent of the pelvic ligament sacrouterina. This ligament provides major support to the cervical and upper vaginal wall. ${ }^{2}$ In vitro studies showed that the cervical portion of the ligament sacrouterina accounted for more than $17 \mathrm{~kg}$ of weight before declining in function. ${ }^{7}$

The main elements of the network stability is quantity, ultrastructure and organization of extracellular matrix proteins such as elastin and connective tissue integrity colagen. ${ }^{7}$ Those things are dependent to the lysyl oxidase (LOX), an extracellular enzyme associated with the extracellular matrix and collagen elastin. ${ }^{6}$
Goepel in 2007, which examined the expression of elastin and tenascin ligament sacrouterina based on a particular age group (POP incidence studies on postmenopausal women) is not appropriate. The phenomenon of the iceberg (iceberg phenomenon) can not be detected prolapse patients of reproductive age. ${ }^{8}$ This is clearly detrimental to the patient because of the efforts of preventive and early treatment becomes possible.

The fact that the abnormality of the supporting structure of connective tissue or the repair mechanism may predispose women to suffer POP is the basic of this study that has not been done in Makassar, so with this background, the research was conducted.

We expect the results of this study showed that the expression of elastin in women with POP may contribute to understanding the etiology of prolapse itself.

\section{METHOD}

The research was conducted in some parts of the teaching hospital of obstetrics and gynecology Medical Faculty of Hasanuddin University to research the subject of a teaching hospital, among others: BLU RS Dr. Wahidin Sudirohusodo and other affiliated hospitals. Laboratory examination of tissue pathology Anatomical Pathology Section Hasanuddin University School of Medicine.

This study was conducted from January 2011 to April 2012. This study was a cross-sectional aimed to determine the differences between elastin expression in women with and without pelvic organ prolapse. The subjects were women with severe pelvic organ prolapse (level III and IV) and without prolapse who were willing to join the study and met the inclusion criteria.

First, the researcher explains the purpose and goals of research to pelvic organ prolapse patients who participated in this study, previous participants who agreed to participate in the study signed a consent form that has been provided. Filling out the questionnaire on the sheet that has been provided, in the form of charging results anamnesis, physical examination and investigation.

Samples were fixed in a plastic bottle containing a solution of $10 \%$ neutral buffered formalin and then sent to a pathology laboratory for immuno- 
histochemical examination using indirect immunoenzyme technique using the labeled streptovidin complex. Interpretation of elastin expression obtained from histopathological examination with immunohistochemical staining.

Analysis of the data used in this study is the chisquare test, Fisher exact test, Mann Whitney test and non-parametric tests. All data presented in the form of narrative and tables. The data were processed using SPSS for windows version 17.

\section{RESULTS}

Distribution of relationship characteristics between the groups of patients with and without pelvic organ prolapse of pelvic organ prolapse in this study it appears that the characteristics of patients with pelvic organ prolapse ever at the age of 45 years, and we compare the same number in the age of the controls without suffering from pelvic organ prolapse.

Most subjects in the pelvic organ prolapse group had $>3$ children (80.0\%), similar with control group, where most subjects also had $>3$ children (54.3\%).

Types of labor history at prolaps group with a history of pelvic organs are normal delivery ie 32 cases $(9.4 \%)$, while in the group without pelvic organ prolapse as many as 27 cases $(77.1 \%)$.

In this study, the weight of baby delivered classified as $\leq 3,500$ grams and $<3,500$ grams. In the pelvic organs prolapse group, there were 7 cases $(20.0 \%)$ who had delivered babies $>3,500 \mathrm{gr}$, while in the group without pelvic organ prolapse there were 5 subjects $(14.3 \%)$ who had delivered babies weighted $>3,500$ gr.

The subject's menopausal status in this study was classified into premenopausal and postmenopausal. In the group of pelvic organ prolapse, there were 31 subjects $(88.6 \%)$ who had experienced menopause, while in the control group without prolapse, there were 21 subjects $(60 \%)$ who had not experienced menopause.

In this study, the subjects were categorized as having a normal BMI if the BMI was 18.5 to 24.99 and as obese if it was $>25$. In the group of subjects suffering pelvic organ prolapsee, as many as 24 cases $(68.6 \%)$ had BMI $>25$, while in the group without prolapse, there were 22 subjects $(62.9 \%)$ with normal BMI, and only 13 subjects (37.1\%) had
BMI $>25$.

Table 1. The characteristic of the subjects with POP and subjects not experiencing POP

\begin{tabular}{|c|c|c|c|c|}
\hline \multirow{2}{*}{ Characteristic } & \multicolumn{2}{|c|}{ POP } & \multicolumn{2}{|c|}{ No POP } \\
\hline & $\mathbf{n}$ & $\%$ & $\mathbf{n}$ & $\%$ \\
\hline \multicolumn{5}{|l|}{ Age (years) } \\
\hline$\leq 45$ & 2 & 5.7 & 2 & 5.7 \\
\hline$>45$ & 33 & 94.3 & 33 & 94.3 \\
\hline \multicolumn{5}{|l|}{ Parity } \\
\hline 0 & 2 & 5.7 & 4 & 11.4 \\
\hline $1-2$ & 5 & 14.3 & 12 & 34.3 \\
\hline$\geq 3$ & 28 & 80.0 & 19 & 54.3 \\
\hline \multicolumn{5}{|l|}{ Type of previous delivery } \\
\hline Nullipara & 2 & 5.7 & 4 & 11.4 \\
\hline Spontaneous delivery & 32 & 91.4 & 27 & 77.1 \\
\hline Operative delivery & 1 & 2.9 & 0 & 0 \\
\hline Sectio Caesarea & 0 & 0 & 4 & 11.4 \\
\hline \multicolumn{5}{|l|}{ Baby's weight } \\
\hline$\leq 3500$ gram & 28 & 80.0 & 30 & 85.7 \\
\hline > 3500 gram & 7 & 20.0 & 5 & 14.3 \\
\hline \multicolumn{5}{|l|}{ Menopause Status } \\
\hline Premenopause & 4 & 11.4 & 21 & 60 \\
\hline Menopause & 31 & 88.6 & 14 & 40 \\
\hline \multicolumn{5}{|l|}{ BMI } \\
\hline Normal & 11 & 3.4 & 22 & 62.9 \\
\hline Overweight & 24 & 68.6 & 13 & 37.1 \\
\hline
\end{tabular}

From 35 patients in the group with pelvic organ prolapse, the elastin intensity was mostly weak, which was found in 26 cases (74.3\%), whereas in the control group, most subject was found to have a moderate elastin intensity (48.6\%).

Table 2. The expression of elastin in the sacrouterina ligament in the group with POP and without POP

\begin{tabular}{lrrrrrc}
\hline \hline \multirow{2}{*}{$\begin{array}{c}\text { Elastin } \\
\text { expression }\end{array}$} & \multicolumn{2}{c}{ Prolaps } & \multicolumn{2}{c}{ No Prolaps } & \multicolumn{2}{c}{ Total } \\
\cline { 2 - 7 } & $\mathbf{n}$ & \multicolumn{1}{c}{$\%$} & $\mathbf{n}$ & $\%$ & $\mathbf{n}$ & $\%$ \\
\hline Weak & 26 & 74.3 & 5 & 14.3 & 31 & 88.6 \\
Moderate & 8 & 22.8 & 17 & 48.6 & 25 & 71.4 \\
Strong & 1 & 2.9 & 13 & 37.1 & 14 & 40.0 \\
\hline Total & 35 & 100 & 35 & 100 & 70 & 100 \\
\hline \hline
\end{tabular}

In Table 2, it was indicated that there are differences in the expression of elastin in both group with POP and the control group. The expression of elastin in the group with POP tends to be weaker when compared with the control group. Results of Mann-Whitney test to compare the elastin intensity 
Table 3. The analysis of risk factors of POP

\begin{tabular}{|c|c|c|c|c|c|c|c|}
\hline \multirow{3}{*}{$\begin{array}{l}\text { Risk } \\
\text { Factor } \\
\text { POP }\end{array}$} & \multicolumn{6}{|c|}{ Elastin expression } & \multirow{3}{*}{$\mathbf{p}$} \\
\hline & \multicolumn{3}{|c|}{ POP } & \multicolumn{3}{|c|}{ No POP } & \\
\hline & $\mathbf{W}$ & $\mathbf{M}$ & $\mathbf{S}$ & $\mathbf{W}$ & $\mathbf{M}$ & $\mathbf{S}$ & \\
\hline \multicolumn{8}{|l|}{ Age (year) } \\
\hline$\leq 45$ & 1 & 1 & 0 & 0 & 0 & 2 & 0.301 \\
\hline$>45$ & 25 & 7 & 1 & 5 & 17 & 11 & \\
\hline \multicolumn{8}{|l|}{ Parity } \\
\hline 0 & 2 & 0 & 0 & 1 & 1 & 2 & 0.224 \\
\hline $1-2$ & 3 & 2 & 0 & 2 & 5 & 5 & \\
\hline$\geq 3$ & 21 & 6 & 1 & 2 & 11 & 6 & \\
\hline \multicolumn{8}{|l|}{ Type of previous de- } \\
\hline livery & 2 & 0 & 0 & 1 & 1 & 2 & 0.459 \\
\hline Nullipara & 23 & 8 & 1 & 3 & 15 & 9 & \\
\hline Spontaneous delivery & 1 & 0 & 0 & 0 & 0 & 0 & \\
\hline Operative delivery & 0 & 0 & 0 & 1 & 1 & 2 & \\
\hline Sectio Caesarea & & & & & & & \\
\hline \multicolumn{8}{|l|}{ Baby's weight } \\
\hline$\leq 3500$ gram & 22 & 5 & 1 & 4 & 14 & 12 & 0.655 \\
\hline > 3500 gram & 4 & 3 & 0 & 1 & 3 & 1 & \\
\hline \multicolumn{8}{|l|}{ Menopause Status } \\
\hline Premenopause & 2 & 2 & 0 & 4 & 9 & 8 & 0.009 \\
\hline Menopause & 24 & 6 & 1 & 1 & 8 & 5 & \\
\hline \multicolumn{8}{|l|}{ BMI } \\
\hline Normal & 9 & 2 & 0 & 2 & 9 & 11 & 0.013 \\
\hline Overweight & 17 & 6 & 1 & 3 & 8 & 2 & \\
\hline
\end{tabular}

W: weak, M: moderate, S: strong

between the two groups showed significant results $(\mathrm{p}<0.05)$.

In Table 3 the results obtained from 35 subjects in group with pelvic organ prolapse compared with 35 subjects in control group without pelvic organ prolapse, obtained significant results on menopausal risk factors and $\mathrm{BMI}>25 \mathrm{~kg} / \mathrm{m}^{2}$ (overweight) as a significant risk factor for the decreasing intensity of elastin (all with $\mathrm{p}<0.05$ ).

Risk factors such as age, education, parity, history of previous type of delivery, and a history of delivering large babies showed no significant results (all with $\mathrm{p}>0.05$ ). But it can be seen in Table 3 that elastin expression correlated with a decrease in intensity when linked with the incidence of pelvic organ prolapse.

\section{DISCUSSION}

Most subjects in the group with POP were above 45 years $(93.4 \%)$. We matched the control group to determine whether age is a risk factor of POP based on the difference of the intensity of elastin expression. The average age was taken on the grounds of age 45 years of age is a premenopausal age. This is consistent with Swift study, saying that POP level I or II mostly occurs in younger women. ${ }^{4}$ Meanwhile, POP level III and IV occur mostly at the age of 40 years and the prevalence increased to $21 \%$ in women aged over 70 years.

Most subjects in the pelvic organ prolaps group had $>3$ children (80\%). This is consistent with Chiaffarino et al, who stated that women with higher parity had a higher risk for the occurrence of genital prolapse (OR 2.6). Compared with women who had never given birth, the OR for women with one vaginal delivery is 3.0 , and 4.5 for women with 2 or more vaginal delivery. This supports the hypothesis that vaginal delivery results in significant tissue damage in the pelvic floor and pudendal nerve in all women who gave birth to her baby, which can result in the looseness of ligament in the pelvic area.

The most common type of delivery in patients 
in POP group was normal parturition or vaginal parturition (91.4\%). This is consistent with research by Lukacz et al which demonstrated a protective effect of cesarean delivery operation in the development of pelvic organ prolapse and stress urinary incontinence urine. ${ }^{9}$ The incidence of pelvic organ prolapse in nulliparous, cesarean operation and high parity women with vaginal delivery is $4 \%, 4 \%$, and $8 \%$.

Most patients in the POP group delivered baby weighted below or equal to 3500 grams $(80 \%)$. This is not consistent with studies Chiaffarino, which said that the estimated OR for pelvic organ prolapse was 0.9 in women who delivered infants weighting 3500 grams or more, compared with women who gave birth to smaller. ${ }^{3}$

Almost all patients in the POP group were already menopause $(88.6 \%)$. The hypothesis is that it is a secondary cause of various factors involved, such as the decline in estrogen during the postmenopausal period. Chen found estrogen receptors in the vaginal wall and sacrouterina ligament of premenopausal women but the amount of it was decreased in the vaginal wall of postmenopausal women. ${ }^{10}$

As much as $68.6 \%$ of the patients in the POP group were obese $(\mathrm{BMI}>25)$. This is consistent with research by Hendrix, which concluded that obesity had also a very strong influence on the basic functions of the pelvic. ${ }^{11}$ Women's Health Initiative (WHI) found that patients with $30 \%$ of the patients a body mass index (BMI) $25-30 \mathrm{~kg} / \mathrm{m}^{2}$ suffered uterine prolapse, $38 \%$ suffered rectocele and $39 \%$ suffered cystocele. ${ }^{11}$

In this study, the expression of elastin sacrouterina ligament decreased in women with POP compared to those without POP. These data lead to the conclusion that elastin plays an important role in the pathophysiology of POP, meaning that decreasing intensity of elastin in women could lead into POP, but the factors that influence the formation of elastin fibers has yet to be known. ${ }^{8}$

Connective tissue abnormalities in the ligament that support the pelvic floor is believed to cause interference with the pelvic floor. With a significant decrease in intensity of elastin in the sacrouterina ligament of women with POP, the underlying theory of decreasing elasticity of the ligament contributes in reducing ancillary functions in the ligament of patients with POP.
One of the most important part of the pelvic support system is sacrouterina ligament. This ligament is the main support of the cervix and upper vaginal wall. ${ }^{2}$ In vitro studies showed that the cervical portion of the sacrouterina ligament supports more than $17 \mathrm{~kg}$ of body weight before declining in function. $^{7}$

Significant risk factors found in this study were menopausal status and BMI $>25 \mathrm{~kg} / \mathrm{m}^{2}$ (overweight). In menopause women, the level of estrogen will decline, causing decompensation of the tissue. $^{10}$

Eventhough other risk factors such as age, parity, history of previous delivery, and the history of baby birth weight showed no significant results, but the results obtained suggest an association to the decreased expression of the intensity of elastin.

Age appeared to be associated with a decrease in the intensity of elastin. At the age of 45 years, there were 25 patients suffering POP with weak intensity of elastin, 7 patients with moderate elastin intensity, and 1 patien with strong elastin intensity. Whereas in the group of patients without POP, there were 5 patients with weak elastin intensity and 17 patients with moderate intensity.

In patients with 3 parities or more, there were 21 POP patients with weak elastin intensity, 6 patients with moderate intensity, and 1 patients with strong intensity. Whereas in the group of patients without POP, there were 2 patients with weak elastin intensity, and 11 patients with moderate elastin intensity. This suggests an association of 3 parities or more with the decrease in the intensity of elastin.

Levator ani muscles and ligaments work together to support the pelvic organs. Delancey describes the phenomenon of "boat floating in the water with both sides tied with rope to the dock". The ship analogy represents pelvic organs, water represents the levator ani muscle, water represents the levator ani muscle, endopelvic fascia and straps represent the supporting structures. If the water is reduced, it will cause the position of the ship down and cause the strap serves to maintain the ship in an overload will loosen or broken. If the analogy with levator ani as a proponent, with the weakness of the levator ani muscle, connective tissue, transferred to advocate for maintaining the position of the pelvic organs, and at some point the load will cause excessive connective tissue to no 
longer functioning. This was followed by pelvic organ prolapse is likely followed by urine incontinence. $^{12}$

\section{CONCLUSION}

Elastin expression in ligament sacrouterina is weaker in women with severe pelvic organ prolapse (level III and IV) and was stronger in women without pelvic organ prolapse. In this study, a significant risk factor for the occurrence of pelvic organ prolapse is a decreasing elastin intensity, menopausal status and overweight status (BMI > $25 \mathrm{~kg} / \mathrm{m}^{2}$ ). Further research with a larger sample size and on the molecular level is still needed in order to investigate the expression of elastin as the pathogenesis of uterine prolapse. It is also necessary to study the elastin levels in the blood so it can be used as a prognostic tools that is easier to achieve than the tissue of sacrouterina ligament.

\section{REFERENCE}

1. Patel PD, Amrute KV, Badlani GH. Pelvic organ prolapse and stress urinary incontinence: A review of etiological factors. Indian J of Urology 2007.

2. DeLancey JOL. The hidden epidemic of pelvic floor dysfunction: Achievable goals for improved prevention and treatment. Am J Obstet Gynecol 2005; 192: 5.
3. Chiaffarino F. Reproductive factors, family history, occupation and risk of urogenital prolapse. European Obstet \& Gynecol J 1999; 82: 63-7.

4. Swift S, Tate SB. Correlation of symptoms with degree of pelvic organ support in a general population of women: What is pelvic organ prolapse? Am J Obstet Gynecol 2003; 189: 2.

5. Barsoom RS. Uterine Prolapse. Available at http://www. emedicine.com. Last updated Jun $12^{\text {nd }} 2009$.

6. Klutke J, Qing Ji, et al. Decreased endopelvic fascia elastin content in uterine prolapse. Acta Obstet et Gynecol 2008; 87: 111-5.

7. Ewies $\mathrm{AA}, \mathrm{Al}$-azzawi $\mathrm{F}$ et al. Changes in extracellular matrix proteins in the cardinal ligaments of post-menopausal women with or without prolapse: a computerized immunohistomorphometric analysis. Hum Reprod 2003; 18: 10.

8. Goepel C. Differential elastin and tenascin immunolabeling in the uterosacral ligaments in postmenopausal women with and without pelvic organ prolapse. Acta histochemica 2008; 110: 204-9.

9. Lukacz ES, Lawrence JM, Contreras R, Nager CW, Luber KM. Parity, mode of delivery and pelvic floor disorders. Obstet Gynecol 2006; 107: 1253-60.

10. Chen GD. Pelvic floor dysfunction in aging women. Taiwan J Obstet Gynecol 2007; 46: 374-8.

11. Hendrix SL, Clark A, Nygaard I, Aragaki A, Barnabei V, McTiernan. Pelvic organ prolapse in the women's health initiative. Gravity and gravidity. Am J Obstet Gynecol 2002; 195:23-8.

12. Valaitis SR. Anterior Compartment Prolapse, Urinary Incontinence, and the Effects of Anterior Colporrhaphy and Paravaginal Repair. In: Lentz GM, ed. Urogynecology. London: Arnold 200: 118-34. 